\title{
PLANNING AND THE SPATIAL SOLUTION OF FORTIFIED URBAN STRUCTURES IN SECULAR POWER CENTRES BUILT BY THE LIVONIAN BROTHERS OF THE SWORD (1202-1237)
}

\author{
Silvija Ozola \\ Riga Technical University, Latvia
}

\begin{abstract}
On conquered lands inhabited by the Balts, brothers-knights built stone castles with chapels and churches in order to implement Crusaders' policy. The location of cult buildings adapted to the terrain and traffic roads influenced planning and architectonic space of secular power centres created by the Livonian Brothers of the Sword (Latin: Fratres militice Christi Livoniae, German: Schwertbrüderorden; 1202-1237). Research goal: analysis of planning of fortifird urban structures in order to determine the cult buildings' impact on the layout and the spatial solution of power centres created by the Livonian Brothers of the Sword. Research problem: the influence of cult buildings' location on construction of power centres designed by the Livonian Brothers of the Sword have not been studied sufficiently. Research novelty: detailed studies of construction of fortified courtyards adapted to the terrain and environment. Research methods: analysis of archive documents, projects and cartographic materials of urban planning, as well as study of published literature and inspection of buildings in nature. Keywords: castle, chapel, fortified building structures, the Livonian Brothers of the Sword, planning of the city center.
\end{abstract}

\section{Introduction}

Jerusalem ( $4^{\text {th }}$ millennium BC) at the Mount Ophel's foot on lands suitable for farming situated far away from trading places on the Mediterranean and the Dead Sea coasts and developed by the only road that took over cliffs. The second ruler of Israel (1020-931 BC) David (around 1005-965 BC) founded the city of David (Arabic: Madina Dawud) (Fig. 1) and built fortified residence on the top of the Temple Mount (Arabic: al-Haram al-Šarīf) surrounded by deep valleys. His son, the king (around 965-928 BC) Solomon extended the area surrounded by defensive walls, and engineers from Tyre (Latin: Tyrus, now Sour), according to samples of Phoenician temples. built the Holy Solomon's Temple (Latin: Templum Solomonis; 957 BC, destroyed in 587 BC) on the Temple Mont. consisted In the Great or Outer Court of the Holy Solomon's Temple, people assembled to worship. The Inner Court of Priests and the Temple building itself, with Holy Place and the smaller "inner sanctum". 
In Jerusalem, Christians knocked down the Venus Temple to restore the worship place. They discovered ancient Jewish burial sites. The burial chamber and antechamber - a grave with a stone bed for the body (Latin: arkosolium) was acknowledged as the Jesus's burial site. Architects Zenobius and Eustace under the Roman Emperor (306-337) Constantinus I Magnus’ mother St. Helen (around 250-330) instruction built the Church of the Holy Sepulchre (Latin: ecclesia Sancti Sepulchri, German: Grabeskirche, Kirche des Heiligen Grabes) or the Church of the Anastasis (German: Auferstehungskirche, Anastasis, Russian: Воздви́жение Честно́го и Животвори́щего Креста́ Госпо́дня; 325/326-335, destroyed in 1009). In the central part of the five-aisled basilica (Latin: martyrium), high walls of rotunda (Italian: rotonda, Latin: rotundus) supported the dome. The Church of the Anastasis with a bell tower, built next around 330, solemnly was consecrated on 14 September 335. On the Temple Mount's western slope, the north-south orientated Cardo Maximus in the $2^{\text {nd }}$ century was Aelia or Helya Capitolina, reached in the $5^{\text {th }}$ century the $21 \mathrm{~m}$ width and became the centre of economic life. The Cardo Maximus finished at the Roman garrison camp, where the east-west orientated Decumanus Maximus crossed it in the right angle. A floor mosaic of Jerusalem map (Fig. 2) as part of the Middle East map in the early Byzantine church of Saint George at Madaba is the oldest surviving original cartographic depiction of the Holy Land (Latin: Terra Sancta) or Palestine.

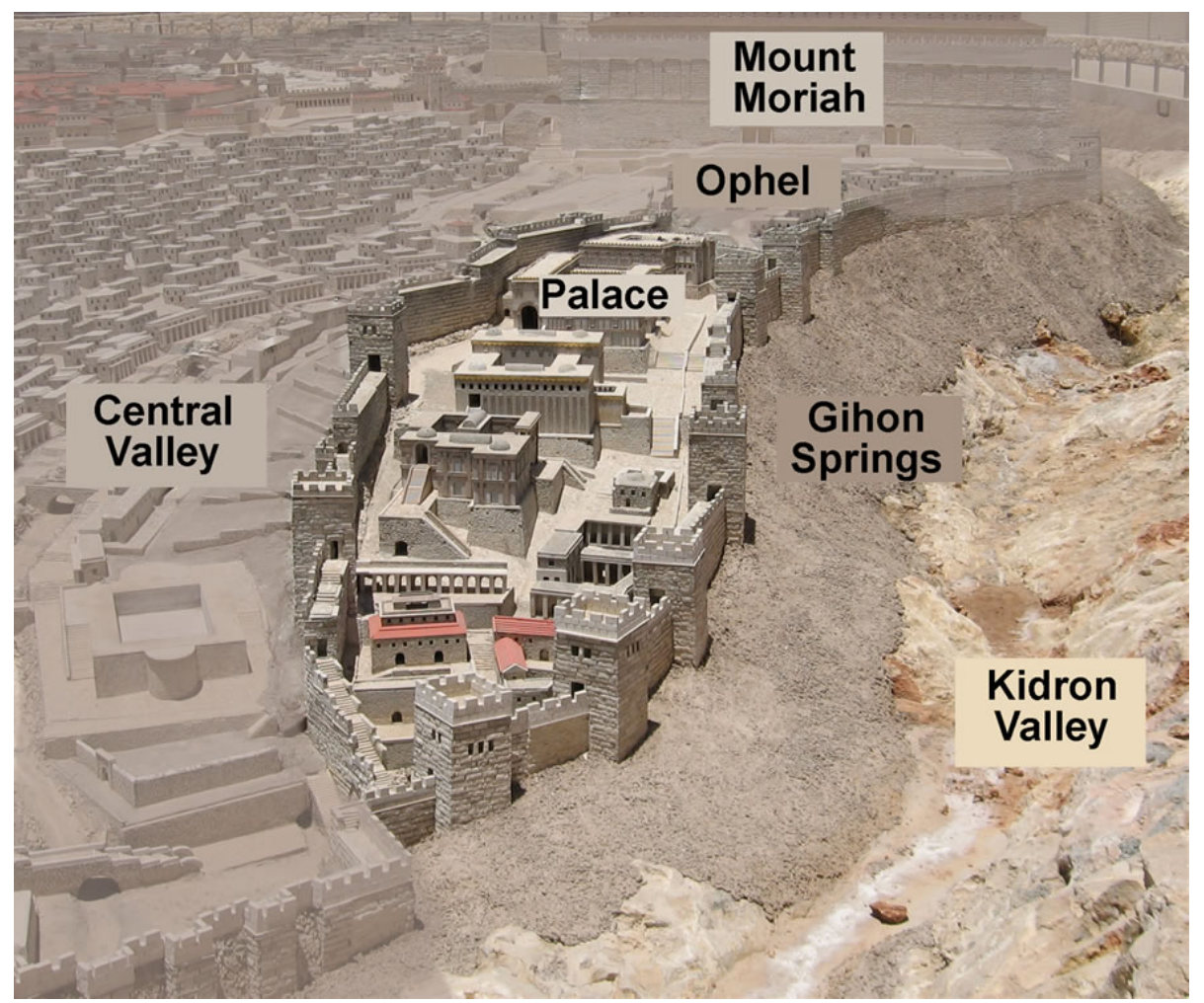

Figure 1 Hans Kroch. Holyland Model of Jerusalem in Israel Museum. 1966 (online 25.05.2017, source: http://www.generationword.com/jerusalem101-photos/city-ofdavid/city-of-david-model.jpg) 


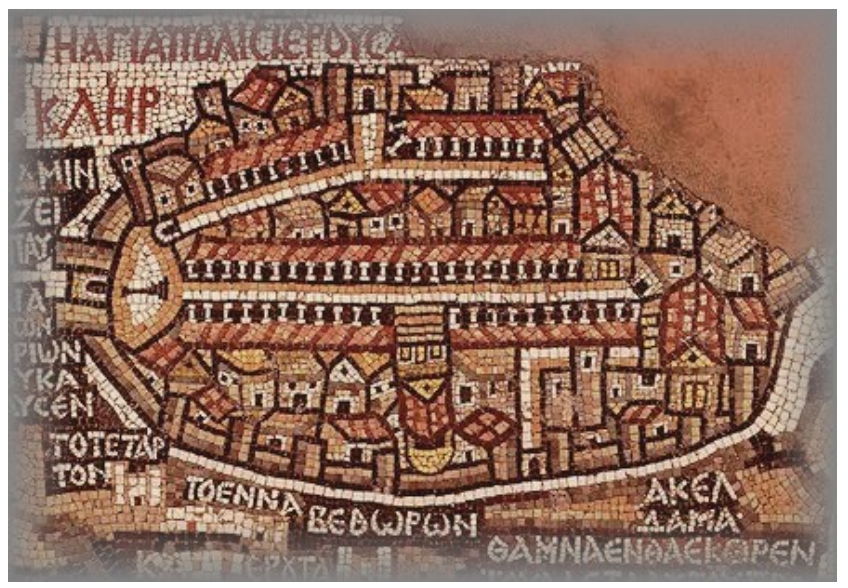

Figure 2 The oldest surviving original cartographic depiction of Jerusalem - a floor mosaic (560-565) in the early Byzantine church of Saint George at Madaba (also Medeba, Jordan)

(online 19.06.2017, http://cdn.secretearth.com/production/84448/banner_84448.jpg)

In Bethlehem (Arabic: Bayt Lahm) over the west-east orientated rocky caves, whose eastern part is considered to be the birthplace of Jesus Christ, the Emperor Constantinus I ordered to build the Basilica of the Nativity (Italian: Basilica della Natività; 327-339, burnt down in the $6^{\text {th }}$ century) or the Basilica of Constantine, which was consecrated on 31 May 339. Under the pulpit in the underground temple, the Christians' most important sanctuary, a silver star in semicircle niche marked the Christ's birthplace. People believed that after visiting St. Maria Latina Church on the northern side of the Benedictine monastery yard (Latin: claustrum, French: cloitre) in Jerusalem and both main churches in the Holy Land, it is possible to obtain material, physical and religious support (Šterns, 2002, 26).

Pope (1145-1153) Eugenius III issued (1145) the bull about the necessity to organize the second Crusade (1147-1149). Bernardus Claraevallensis invited the Brothers of the Order to become missionaries and preach Christianity in pagan lands (Spekke, 2008, 113). Brothers-knights rebuilt the Church of the Anastasis and solemnly consecrated on 15 July 1149.

In Western Europe, when the decline of crusades settled in, the Holy Roman Empire had interest about regions inhabited by the Baltic tribes. People, making defensive buildings of wood and soil, improved security of wooden dwellings in places protected by natural obstacles. The Üxküll (also Uexküll or Yxkull, Latvian: Ikšķile) Bishopric (Latin: Episcopatus Ixcolanensis; 1186-1201) was established, and the knights were encouraged for the fourth Crusade (1202-1204) and military aggression against the Livs. The territorial subjugation has been expanded for the implementation of economic needs, and strategic considerations were determinant ones. Applying new constructive means, the knights built irregular layout fortified yards for residences with cult buildings, support places and secular power centres on peninsulas or capes. Earliest news on the building of the Balts, the Finno-Ugric 
and newcomers comes from chronicles. Benedictine Abbot (since 1177) at the Monastery of Saint John (German: St.-Johannis-Kloster; 1177) Arnoldus Lubecensis (around 1150-1211/1214), who in the Lübeck Port (German: Lübecker Hafen) from the late $12^{\text {th }}$ century probably watched the knights' and missionaries' gather for a trip to Livland (Mugurēvičs, 2000, 36), wrote “Arnoldi Chronica Slavorum"/Arnold Chronicle/ (1171-1209) as a continuation of "Helmol's Chronica Slavorum". Priest at Bosau near Plön, Saxon historian of the $12^{\text {th }}$ century Helmold (around 1120-after 1177) was a friend of two bishops of Oldenburg in Holstein, Vicelinus (died 1154) and Gerold (died 1163), who did much to Christianize the Polabian Slavs. Arnoldus for the first time in Western Europe informed about the subjugation of lands inhabitat by the Balts. He also included news about the history of Lübeck, the going of the third (1189-1192) and the fourth Crusades and life of Henry the Lion (German: Heinrich der Löwe; 1129/1131-1195), Duke of Saxony, as Henry III, from 1142, and Duke of Bavaria, as Henry XII, from 1156, the duchies of which he held until 1180. At the height of his reign, Henry as one of the most powerful German princes of his time ruled over a vast territory stretching from the North and Baltic Seas coasts to the Alps, and from Westphalia to Pomerania, achieved great power in part by his political and military acumen and in part through legacies of his four grandparents, until the rival Hohenstaufen dynasty succeeded in isolating him and eventually deprived him of his duchies of Bavaria and Saxony during the reign of his cousin Friedrich I Barbarossa and of Frederick's son and successor Henry VI.

Catholic Priest Henricus de Lettis (around 1187-after 1259), using Archives of Bishop and the Canonical Chapter, wrote "Heinrici Chronicon Livoniae" (the Livonian Chronicle of Henry; 1224/1226, released in 1993) about events of 1180-1227 (Heinrici, 1993) and the Livonian Brothers of the Sword (German: Schwertbrüder) and the addition (1227) - primary sources of Latvian and Estonian history. The chronicle "Livländische Reimchronik, or Älteste Livländische Reimchronik" /The Livonian Rhymed Chronicle, or the Oldest Livonian Rhymed Chronicle/ was written between 1290 and 1296 on events since the beginning of Catholic Priest Meynardus's (Latin: Meinnardus, German: Meinhart, Meinhard von Segeberg; around 1130/1140-1196) mission until the close of the Semigallia's conquest after 1290 (Livländische, 1876; Atskan,u, 1998). Priest, chronicler Christian Kelch (1657-1710) wrote the history of Livonia (Kelch, 1695), but jurist, burgomaster, careful collector of archive materials on Livonian history, historian Friedrich Konrad Gadebusch (1719-1788), considered an "extremely hard-working", wrote a treatise by Livonian historians (Gadebusch, 1772) and a look at castle ruins in Livonia (Gadebusch, 1846). Professor Leonid Arbusow (Russian: Леонид Арбузов; 1848-1912) studied the history of the Livonian Brothers of the Sword (Latin: Fratres militice Christi Livoniae; 1202-1237) (Arbusow, 1904). Latvian painter, 
archaeologist, ethnographer Ernests Brastinš (1892-1942) since 1922 surveyed hillforts of Latvia and made their topographic plans. Latvian writer, literary scholar Antons Birkerts (1876-1971) published in the Republic of Latvia the first scholastic book „Latvijas vēsture: pamatskolas kurss”/History of Latvia: Elementary School Course/ and in the next edition used works (Švābe, 1921, 1922) written by the founder of Latvian national history, Dr. iur. Professor of University of Latvia Arveds Švābe (1888-1959). In 1937 the description of Latvia history (Senās, 1937) and a guidebook around Native Land (Vanags, 1937) written by the founder and creator of ideology of the tourism in the 1930s Kārlis Vanags were published. Historian, Candidate of historical sciences Teodors Zeids (1912-1994) analysed written historical sources (Zeids, 1992) and prepared chapters on the Crusades for the first volume (Latvijas, 1953) included in a collaborative work (1953-1959) of the history of Soviet Latvia. Historian, Dr. phil. Friedrich Wilhelm Benninghoven (1925-2014) studied activities of the Livonian Brothers of the Sword (Benninghoven, 1965). Studies on ancient trackways (Pāvulāns, 1971) has been published by researcher of Latvian medieval history, pedagogue, academician, Dr. hab. Vilnis Pāvulāns (1938-1994). Prominent Latvian historian, Dr. Ph. Professor emeritus of Muhlenberg College (USA) Indrikis Šterns (1918-2005) published a history of the Crusades (1180-1290) on the territory of Latvia (Šterns, 2002), but the history of Latvia written by diplomat, historian, Dr. phil. Professor (since 1922) Arnolds Spekke (1887-1972) was released in 2008.

Prominent researcher of fortresses in the Baltics, historian of art, Dr. phil. Professor at the University of Tartu Armin Tuulse (until 1936 Armin Neumann; 1907-1977) prepared a summary research about architecture of medieval castles in Estonia and Latvia and published in the monograph about castles in Estonia and Latvia. Tuulse believed, that early construction period (1185-1237) of castles related to fortifications built in Üxküll Village (Latvian: Ikškile, Liiv: ikš (ükšs) + kila or one + village) of the Livs during the reign of Bishop Meinhart (Latin: Meynardus, Meinnardus, middle upper German: Meynhart; around 1130/11401196) and castles built by the Livonian Brothers of the Sword under the leadership of Bishop Albert in newly conquered territories (Tuulse, 1942). Archaeologist of the Institute of Latvian history, Dr. hab. hist. Professor Ëvalds Mugurēvičs (b. 1931) solved questions on classification and archaeological research of castles in Latvia (Mugurēvičs, 1983). In the sixth book of the guidebook series "Памятники искусства Советского Союза" /Monuments of Art of the Soviet Union/, which was devoted to the most significant architectural monuments and related works of monumental and decorative art, as well as sculptural monuments and memorial complexes of Belarus, Lithuania, Latvia and Estonia, essays on the development of architecture and illustrations were included. References contains descriptions of reproduced architectural monuments, their chronological list, 
bibliography and names of architects, painters and sculptors (Алттоа, Васильев 1986). Honorary Doctor of the Latvian Academy of Sciences, Dr. hist. Jānis Apals (1930-2011) analysed the building strategy of castles on the Gauja basin district in the $13^{\text {th }}-14^{\text {th }}$ centuries (Apals, 2002). Archaeologist, Dr. hab. hist. Professor Andris Caune (b. 1937) together with his daughter, the full member of the Latvian Academy of Sciences, Dr. hist. Ieva Ose compiled the lexicon of German Castles in Latvia, end of the $12^{\text {th }}-17^{\text {th }}$ century (Caune \& Ose, 2004). Estonian art historian Dr. Anu Mänd, who specialized in the Middle Age, studied Saints' cults played a crucial role in society of Medieval Livonia (Mänd, 2009). Descriptions of 95 historical places, illustrations of 441 plans, cross-sections, reconstructions, historical engravings, archival and contemporary photographs are in the book about cities, castles and monasteries formed in areas of Livonia and Prussia conquered during the crusades (Borowski, 2010) written by Tomasz Borowski, who presents also Teutonic possessions in the Holy Land. Vivi Jensen, Anne Parikka and Bengt Kylsberg collected information on castles around the Baltic Sea (Jensen, Parikka, \& Kylsberg, 2013). Architect, Mg. arch. Assitant Professor Silvija Ozola published research about tower houses and castles (Ozola, 2018b).

Previously studies on Wenden (also Winden, Latvian: Cēsis) Castle: Swedish Army general, military engineer Johan Palmstruck (1611-1671) drawn plan of Wenden stronghold, the ruler's residence in the castle with the fortified urban structures' area. In the late $18^{\text {th }}$ century German pedagogue, ethnographer, painter Johann Christoph Brotze (1742-1823) drawn Wenden stronghold plan (released 2007) and castle ruins (Broce, 2007), but around 1829, Auditor Wilhelm Tusch surveyed Wenden Castle ruins and Revisor Christoph von Kuntze created drawings for a collection named after Governor-General of the Governorate of Livonia, Marquis Filippo Paulucci delle Roncole (1779-1849). The Russia army officer, landlord of the Governorate of Livonia, Count Karl Eberhard von Sievers (1745-1821) in 1777 obtained Wenden Manor House, and around 1840 in Wenden Castle ruins, one of the oldest known archaeological excavations in Latvia was performed under the leadership of Count Emanuel von Sievers (18171909). Regional researcher Jegor von Sivers (1823-1879) in the mid- $19^{\text {th }}$ century prepared the first history studies of Wenden Castle and the town (Sivers, 1852). Researcher of castles Karl Woldemar von Löwis of Menar (1855-1930) made Wenden Castle plan and included it in drawings of stronghold's components (1888). The Board of Monuments decided to survey castle ruins and more detailed study its structure, in order to develop a conservation and restoration project (Dzimtene, 1927), but inspector at Cēsis resort committee Kārlis Dzirkalis (1902-1997) believed, that on the ancient mound Riekstu Hill (German: Nusberg, Latvian: Riekstukalns - Nut Hill), wooden structures should be built similar to ancient inhabitants' dwellings (Dzirkalis, 1935). Erna Berkholce wrote an essay on Wenden construction history (Berkholce, 1952-1953). Specialists of the 
scientific restoration workshop of the Architecture Department of the Latvian Soviet Socialist Republic inspected the medieval castle-fortress, and due to the importance of Wenden Castle as the centre of the Livonian Brothers of the Sword, it was included in the list of historical monuments of the USSR (Loze, 1956). Scientic research of Wenden Castle history started in 1958, when librarian, archivist Aleksandrs Jansons (1916-1991) began to compile a bibliography (Jansons, 1958). Analysis of audit texts and significant descriptions of 1582 and 1590, found in archives of Moscow, greatly made to research the construction of Wenden Castle. Historians Ārija Zeida (1933-1984) and Teodors Zeids studied the development of crafts in Wenden during the feudal era (Zeida \& Zeids, 1961), but Fjodorovs D. carried out the historical research of Wenden Castle (Fjodorovs, 1961). In the mid- 1960s historian, archivist Roberts Malvess (1905-1982) began and with breaks continued to study excerpts from archival materials summarized by Jansons who prepared a base for further research in nature and archives. Malvess is the last, who carried out complex studies of Wenden Castle history and prepared the most extensive historian's study of this castle, carefully weighted the work of previous researchers, historical pictures, analyzed architecture and historical documents. Archaeologist, Dr. hist. h. c. Zigrīda Apala conducted archaeological research of Wenden Castle and collected materials (Apala, 2007). Architect Ilgonis Alfs Stukmanis (b. 1935) prepared a description of research on Wenden Castle and reviews of conservation works, but architect, Dr. arch. Ilmārs Dirveiks carried out architectural-artistic inventory (Dirveiks, 2002) and architectural research of the castle. The full member of the Latvian Academy of Sciences, Dr. arch. Jānis Zilgalvis summarized information about the most endangered cultural monuments in Latvia (Zilgalvis, Tapiņa, \& Šnē, 2004) and included Wenden Castle in guidebook of the most notable residences (Zilgalvis, 2000). Historian of culture, teacher, museum worker, litteraturer Jānis Polis (b. 1956) wrote the Chronicle of Cèsis (former Wenden) (Polis, 2006). Historian of Kandava Regional Museum, Mg. hist. Agris Dzenis wrote Wenden Castle's history (Dzenis), and chief of the Medieval Castle Department of Cēsis History and Art Museum, historian Gundars Kalniņš published the history of Wenden Castle in pictures (Kalniņš, 2014, 2017).

Previous studies on Wolmar Castle (Latin: Castrum de Woldemer, German: Schloß Wolmar, Latvian: Valmiera): in the late $18^{\text {th }}$ century Johann Christoph Brotze drawn Wolmar Castle plan (released 2007), but around 1829, Auditor Wilhelm Tusch surveyed Wolmar Castle ruins and Revisor Christoph von Kuntze created its plan and drawings for a collection named after Filippo Paulucci. Regional researcher of Wolmar Wilhelm Friedrich Heine collected historical data on Wolmar Castle and in Stockholm redrawn Swedish fortification plans to include it in the edition dedicated to the history of Wolmar town (Heine, 1893) and notes to the history of Valmiera (former Wolmar) (Heine, 1994). Member of 
the Saeima of the Republic of Latvia, public employee, farmer Hermanis Enzeliņš (until 1897 - Endzeliņ̌š 1867-1953) published articles on this castle in the newspaper "Valmierietis" (1917-1940) and edited a book about Valmiera (1932). Honorary Doctor of the Latvian Academy of Sciences, archaeologist Dr. hist. Elvīra Šnore (1905-1996) in summer of 1937 carried out archaeological research, that in 1938 were continued by archaeologists Hugo Riekstiňš (1904-1998) and Pēteris Stepiņš (1914-1999). Archaeologist Dr. hist. Māris Atgāzis (1935-2018) conducted archaeological excavations in 1972, but in 1978 - archaeologist, Dr. hist., Dr. hab. Art Juris Urtāns (b. 1952), in 1979 - Dr. hist. Tatjana Berga (b. 1944) and historian Laimonis Liepnieks (1927-2001) from Valmiera. Architect Valdis Liepa in 1982 surveyed castle ruins and worked out the conservation project, but Tatjana Berga continued (1980, 1988-1992, 1999, 2001-2008) archaeological researchs, which in 1987 were carried out by archaeologist Natalija Jefimova (b. 1950). In 1995 Tatjana Berga worked together with archaeologist Dr. hist. Viktorija Bebre (b. 1952), who from 1996 to 1998 and in 2000 continued works. Archaeologist Inita Dzelme (b. 1958) carried out archaeological research in 2006 and 2007, but in 2010 she worked together with Berga. In 2013 archaeologist Oskars Ušpelis (b. 1983) continued research (Berga, 2018, 11-12).

Previously studies on Fellin (from 1919 Estonian: Viljandi) Castle: after Fellin plan of 1602, drawn by Jacobus Laubus, researcher Karl von Löwis of Menar created Fellin plan (1914), in which included the castle, front-castles and a settlement. Archaeologist of Viljandi Museum, Professor Henn Harri Moora (1927-2012) studied the evolution of building in medieval Fellin (Moora, 1956), but historian of architecture Elmo Raadik (1925-1969) in collaboration with historian of art, Dr. art. Professor Voldemar Vaga (1899-1999) developed architectural studies (Raadik, 1960).

Research problem: urban plannings and spatial structures of fortresses in Livonian secular power centres created by the Livonian Brothers of the Sword during the $13^{\text {th }}$ century has been studied insufficiently. Research goal: to analyse the construction structure of castles built by the Livonian Brothers of the Sword and the impact of cult buildings on the planning of secular power centres in order to determine main characteristics. Research methods: inspection of castles and urban planning in nature. Foto fixations, archive documents, projects, graphic and cartographic materials have been used for the analysis of castles in power centres built by the Livonian Brothers of the Sword. 


\section{The building of primary fortified power centres of the Livonian Brothers of the Sword}

Bishop Albert in 1201 relocated his residence and cathedral to Riga (Latvian: Rig $a$ ), and once a simple village with a traditional marketplace and spatially and functionally unrelated buildings, was declared a bishopric centre and given it a higher status. For Riga, this was the beginning of the growth not only of German but also of medieval European city (Васильев, 1986). In 1202 Bishop of Riga Albrecht von Buxthoeven (Latin: Adalbertus Canonicus Rigensis; 1165-1229) together with his brother Theodericus (also Thidericus; around 1150-1219), pulling the affinity in the Prince-Archbishopric of Bremen (German: Erzstift Bremen), founded the Livonian Brothers of the Sword, in order to brothersknights participated in military expeditions for the territorial subjugation (Šterns, 2002, 198). During the fourth Crusade the knights under the guidance of its first Master (German: Herrmeister; 1204-1209) Winno von Rohrbach (Latin: Vinnenus, Wenno, Wynno) next to the first Riga Bishop's fortified yard built dolomite Wittenstein or St. George's (sente Uriân) Castle (1204, destroyed in 1297) as fortified yard that included a cult building. The altarpiece of St. George's Church (Fig. 3) created between 1204 and 1209 (Atskaņu, 1998, 330) was directed towards the southeast. In Livonia, the early period of stone fortresses' construction (1185-1237) defined by Tuulse also related to activities of the Livonian Brothers of the Sword. Historian of architecture, Cand. art Jurij Vasiljev (Latvian: Jurijs Vasiljevs; 1928-1993) believed, that the medieval period in architecture of Latvia (the late $12^{\text {th }}$ century-the first third of the $16^{\text {th }}$ century) had several stages. The first stage (the late $12^{\text {th }}$ century-the first third of the $13^{\text {th }}$ century) dates back to the beginning of activities of missionaries and crusaders in basins of the Daugava and the Gauja Waterways (Vasiljev, 1986).

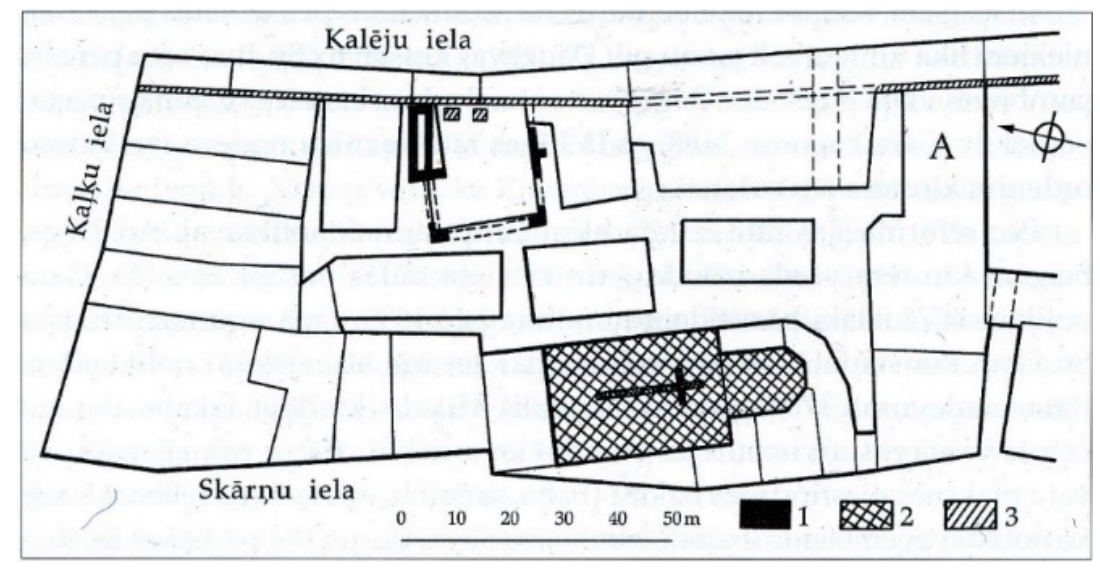

Figure 3 Polish historian I. Górska. The plan of the Livonian Brothers of the Sword St. George's fortified yard: 1 - walls of square layout building, 2 - St George's Church, 3 - defensive wall. 1993 (Caune \&Ose, 2004, 400) 
Ozola, 2020. Planning and the Spatial Solution of Fortified Urban Structures in Secular Power Centres Built by the Livonian Brothers of the Sword (1202-1237)

German merchants no longer wanted to accept the local inhabitants' brokerage in commercial relations, therefore a successful struggle for the Daugava Waterway's control began. Brothers-knights gained one of the biggest Livs' centre Ascrad or Asscrade hillfort (Latvian: Augstais or Krauklu kalns) on the right bank of the Daugava (German: Düna) River and burnt down wooden dwellings, in order to build Alt-Ascheraden (Latvian: Vec-Aizkraukle) Castle (Latin: Asscrad castrum) of stone near the Aškere River estuary in the Daugava (Caune \& Ose, 2004, 158). A freestanding church of stone already in 1225 existed in a settlement at the hillfort's foot.

In 1205 the knights achieved the Livs' port farthest to east and under Bishop Albrecht's guidance in 1207 occupied Kukonoyse (also Kocanois, Latvian: Koknese) country. They strengthened on the left bank of the Daugava and until summer of 1208 destroyed Russian merchants' colony on Kukonoyse hillfort. The trade centre ended to exist (Šterns, 2002, 181-182). During 1208 the knights destroyed all Livonian fortifications on the left bank of the Daugava lower up to Kukonoyse, got their ports and with Bishop Albrecht took over wooden fortifications on the Latgalians' hillfort by steep sides and, following the outline of the destroyed fortress of triangular layout, built two dolomite two-storey blocks mutually placed in a narrow angle, to create Riga Bishop's residence Kokenhusen (1209) Castrum of irregular layout on the cape at the Pērse River estuary in the Daugava. A front-castle surrounded by defensive wall and adapted to plateau relief left behind the residence (Ozola, 2018a).

In 1206, Catholic Priest Alexander arrived in Metsepolis (Livonian: Mõtsa pūol-wooded place, Finnish: metsänpuoli), an ancient Livonian county inhabited by the Finnic Livonians, in order to baptize the locals who lived on the east coast of the Gulf of Riga. The Wends, driven by the Cours, moved to the Latgalians in neighborhood of Segwold (Latvian: Sigulda), Cremon (also Crammon, Latvian: Krimulda) and Treiden (Livonian: Taara aed) or Toreida (Latin: Thoreida, Thoreyda) and accepted the Catholic Faith in 1206. Bishop of Riga in 1207 signed Livs' lands division agreement (in the Livonian Chronicle of Henry: donatio tercie partis Lyvonie fratribus milicie, German: die Teilung des Livenlandes) (Senās, 1937), won Metsepolis and founded on the right bank of the Gauja ecclesiastical state included in the Holy Roman Empire - the Livonian Bishopric (Episcopatus Livoniensis, 1207-1255), that originally was under the control of Archbishop of Bremen (Heinrici, 1993, 369). Priest Alexander began to build the church and created parish mentioned in 1207. The Wends became citizens of the bishopric and loyal allied in fights against the Estonians and the Russians, got under the knights' subordinate, allowed them to stop in one's fortress Wendorum castrum (Šterns, 2002, 196) on the top of Riekstu Hill located at the right edge on the Gauja Valley between Tolowa (Latin: Tholowa, Latgalian: Tuolova Latvian: Tãlava) and the Liv's land Vidumaa (Latin: Ydumea, Latvian: Idumeja, also 
Idums) on the right bank of the Gauja. The beneficial place for trade on banks of the Gauja inhabitad by the Wends, three ferries provided crossing of the river and since unknown times there was a trade route between Riga and Pskov (also Plezcowe, Estonian: Pihkva, Russian: Псков, Krivichean: Пльсковъ), undoubtedly aroused interest of swordsmen. Russian chronicles say, that the Latgalians paid dues for the Russians even before the Germans arrived, and the name of the place was Kecb (Livonian: kest - "on the other side" of the Gauja), from which possibly comes the word "Césis" that occured for the first time in the Livonian Chronicle of Henry. Latvian linguist, the founder of Latvian scientific linguistics and baltology, Doctor of Philology (1912), academician (1946), Professor Jānis Endzelīns (1873-1961), brother of Hermanis Enzeliňš, studied the origin of “Césis" name (Endzelīns, 1931), but archaeologist Jānis Apals published research on the Wends, Riekstu Hill and Wenden town (Apals, 1998, 2007).

In spring of 1208 Bishop Albrecht subjected sovereign Tolowa districts on the right bank of the Gauja. Winno destroyed the Livs' homes on Sattesele (Latvian: Satezele) hillfort and built defensive walls of Segwold fortified yard for Vogt's residence on a cape to control the Gauja Waterway (Heinrici, 1993, 172-175). The first fortifications of Segwold possibly began immediately after the division of land in 1207 and were completed by 1209 (Jemeljanovs, 2014, 132). Close by the yard, single-part rectangular elongated free-standing wooden St. Bertulis Church covered by a ridged roof was built without a tower. The layout combined the square altarpiece (Latin: presbyterium) covered by a cross vault, and just a wide long stretched irregular rectangle parish-room by wooden ceilings.

In the Wends' housing place on the top of Riekstu Hill, the knights after 1207 started to build Old-Wenden (German: Alt-Wenden) fortress, which already in 1210 was built. Initially a repeatedly restored pole fence surrounded dwellings, but later they erected a defensive wall created the yard. Wooden buildings adjoined to walls' inside edge and placed in the yard. The fortress was not built on the bank of the river, but at the intersection of important trade routes, to which led an important road from Lithuania passed by the historical region of Selonia (Latvian: Sélija) and Kokenhusen Castrum and started local routes that crossed the Gauja. Along the left bank, road led to Wolmar and Dorpat (Latvian: Térbata, Estonian: Tartu, Latin: Tarbatum, Russian: Дерnm, since 1893 Юрьев). Riga Segwold - Wenden - Trikaten (Latvian: Trikāta) - Adsel (Latvian: Gaujiena) Marienburg (Latvian: Alüksne) - Pskov road branched, creating to Ronneburg (Latvian: Rauna) direction a sidewalk that originally was the most important commercial highway northeast, and Riga - Treiden - Wolmar - Stackeln (Latvian: Strenči) - Adsel - Pskov trade route (Vasmanis, 2007, 121-123). 
Ozola, 2020. Planning and the Spatial Solution of Fortified Urban Structures in Secular Power

Centres Built by the Livonian Brothers of the Sword (1202-1237)

\section{The urban planning of primary fortified secular power centres of the Livonian Brothers of the Sword}

In Europe, differences in the countries' development and creation of market places caused property disputes. Germanic and Slavic peoples began the fight for the control of important trade routes. The capital of a Slavic principality was the original settlement called Luibice and contained a castle with a merchant town on a harbor. It located on the peninsula at the confluence of the Schwartau with the Trave Rivers. The West Slavs settlement during the uprising of 1138 burned down, and Count of Schauenburg and Holstein (1128-1164) Adolf II of Holstein took over the strategically important peninsula and in 1143 founded Lübeck, the modern town as a German settlement on a hill island of Bucu or Buku surrounded by the Trave and Wakenitz Rivers. German merchants at the Wakenitz estuary in the Trave River established a port (1143) for active trade. It is also the name of ruined medieval Slavic castle on the island. Atop the ruins of Bucu, the Burgkloster, or fortified monastery of Lübeck located. Adolf II built a new castle, first mentioned by chronicler Helmold as existing in 1147, to which a suburb was formed. In the central part of the peninsula, the former urban settlement name locus corresponded to the archaeological account of the origin of the German merchant and craftsman settlement civitas (Mugurēvičs, 1998, 181). The word civitas had several meanings in Medieval Latin texts - also a district or district centre of the secular or spiritual administration for some country. In 1150, the Oldenburg Bishopric was moved to the southern part of the peninsula. Henry the Lion, who forced Adolf II to relinquish Lübeck to him as feodal overlord, no sooner had the town in his possession when a fire destroyed it, and in 1159 he began rebuilding it. This is now considered the traditional date of it founding. Bishop of Oldenburg and Lübeck (?-1163) Gerold moved his residence from Oldenburg to the southern part of Lübeck in 1160 (Šterns, 2002, 59) (Fig. 4). Plots of land for building were allocated on both sides of trade route, which extension was turned into an "elongated" marketplace, creating a planning similar to a "fishbone" to provide an access to the waterway, from which since the late 1160 the Germans went on trips down the Daugava River. In 1173, Henry the Lion founded the Lübeck Bishopric (Hochstift Lübeck; 1180-1803), and Lübeck became the bishopric capital (1173). As the city and its trade on the Baltic grew in importance, special rights and priveleges were granted to it in 1188 by Emperor Friedrich I Barbarossa. In 1226, Friedrich II raised Lübeck to the status of a free imperial city and a long period of self-government began. The commercial importance of the city became even greater when it joined with Hamburg in 1241 to form the nucleus of what was to become the Hanseatic League. 


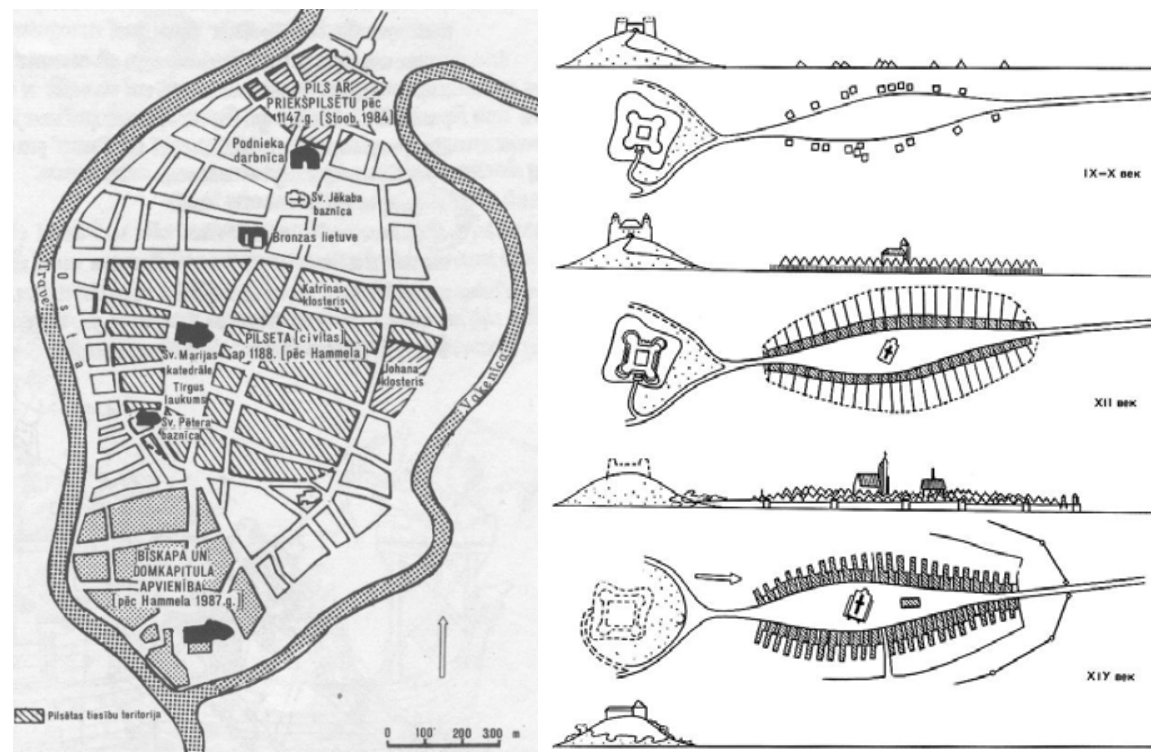

Figure 4 Erdmann. The reconstruction of Lübeck plan at the late $12^{\text {th }}$ century. 1986 (Heinrici, 1993, 407)

Figure 5 Researcher of the urban history, Professor Emanuel Hruška (1906-1989). The local development scheme of the populated area at the hillfort foot in the $10^{\text {th }}$, $12^{\text {th }}$ and $13^{\text {th }}$ centuries (Savarenskaja, 1984, 152)

Architect, urban planner Ernst Arnold Egli (1893-1974), lived in Switzerland, and researcher of the urban history, academician, arch. Ing. arch. Dr. techn. Professor Emanuel Hruška (1906-1989) from Czechia analysed plannings of European medieval towns (Grushka, 1963). After his moving to Switzerland in 1940, Egli became a Swiss citizen and from 1942 held teaching positions at the Swiss Federal Institute of Technology in Zürich. He became titular Professor of urban development in 1947, but from 1947 to 1951 - head of the Department of Urban Development in Beirut. After two years of teaching again in Zurich, he from 1953 to 1956 worked at the University of Ankara. During his time as a university lecturer until 1963, he wrote his basic writings on urban planning (Egli, 1959), which earned him great recognition. In 1968, he received an honorary doctorate at the Vienna University of Technology. Ernst Egli's "Geschichte des Städtebaus" /A history of urban development/ published in three volumes (1959-1967) was the largest attempt to write a general history of urban design at his time. In a fortified town, an "elongated" marketplace in the road extension built-up on both sides took to a fortress or monastery, joined the main gate with the marketplace or the Cathedral Square and public buildings and houses placed in the neighbourhood. Hruška showed, how in vassals' properties road at the castle's foot was gradually built-up from both sides: initially small huts placed in short distances $\left(9^{\text {th }}-10^{\text {th }}\right.$ century), then close terraced buildings were created (12 ${ }^{\text {th }}$ century), and, finally, public buildings as the church and the Town Hall were placed in the road extension ( $12^{\text {th }}-14^{\text {th }}$ century) (Fig. 5). 
In the early $13^{\text {th }}$ century, German origin merchants established settlements at fortresses, that provided them protection. They also settled in Wenden inhabited site near the fortified yard of brothers-knights. In 1221, the building was organized along Riga-Dorpat trade route, that led through the village, connected near and far, small and large places in Livonia and beyond (Broce, 2007, 20-22). In Wenden settlement, where wooden construction in the early $13^{\text {th }}$ century was characteristic, initially, the building consisted of dwellings belonged the local population's village and merchants' prefabricated houses-warehouses. Aisles made of logs between them could be considered as streets. Later in the $13^{\text {th }}$ century, there were mixed type building, that was irregular. Due to the lack of written sources, historians have not described the further development of this building. Craftsmen' and merchants' houses, arranged at Wenden Castle walls in settlement's eastern part, the Livs' plots of land in settlement's southern part, canons' houses and Russian merchants' yard created the medieval agglomeration of oval configuration (Fig. 6).

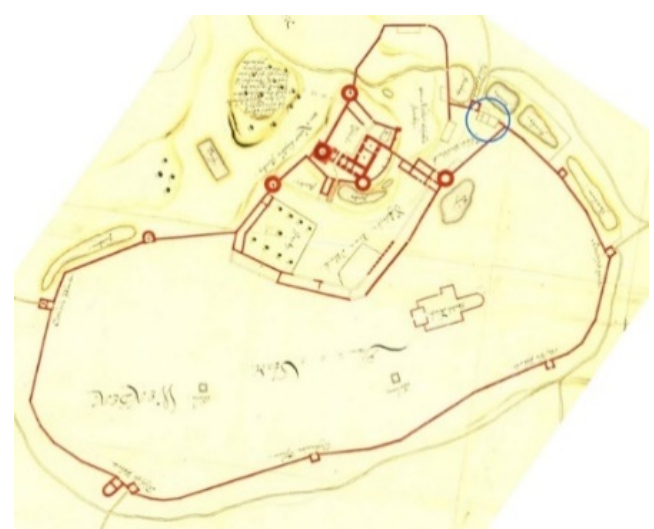

Figure 6 Johan Palmstruck. Plan of Wenden Castle close by Riekstu Hill and the fortified site with the location of St. John's Church instead the former wooden church. The $17^{\text {th }}$ century (Stocholm, Kungl. Krigsarkivet)

In the first quarter of the $13^{\text {th }}$ century, the Wends' or the old fortress and the castle coexisted, and the settlement next to both fortresses became the beginning of Wenden town (Caune \& Ose, 2004, 127), in which German title "Wenden", the Wends' name was preserved (Heinrici, 1993, 368-369). The second biggest Livonian town of Wenden became an important political centre by a marketplace, where the Town Hall for the first time mentioned on 28 July 1226. The Town Hall situated near the northern front-castle wall. In the $13^{\text {th }}$ century the Wends were mentioned by Roman Pope, in the $14^{\text {th }}$ century - by Archbishop of Riga. Further historical sourses no longer mentioned the Wends. 


\section{Specific of fortifications created by the Livonian Brothers of the Sword until the first half of the $13^{\text {th }}$ century}

In 1210, Bishop Albrecht sent knight Arnold to Prince Vladimir of Polotsk (Byelorussian: Полаик, Russian: Полоик) to conclude a contract, in order to involve traders from Riga in direct trade with the Russian. In January of 1211, Elders of Riga (Latin: Seniores Rigensium) under the guidance of Bishop organized the first Crusade to the Estonians' land Suntaken (Estonian: Soontagana; soo - swamp and tagana - behind) in order to monitor traffic to Pskov and Novgorod (also Nogarden or Nogarten, Russian: Великий Новгород; around 5-6 century). Bishop of Riga Albrecht using his conquerors' rights and the knights' help occupied the main economic centre of Saccalia (Estonian: Sakala) Viljandi hillfort surrounded in the $12^{\text {th }}$ century by the constant settlement that was first mentioned in 1154 as Falamus in comments on the "Tabula Rogeriana". In March of 1211 Viljandi hillfort was conquered. The Leal (Latin: episcopatus Lealensis) or the Estonian Bishopric (Latin: Episcopatus Estiensis or episcopatus de Hestia; 1211-1224) was founded in Estonian land Rotalia (Estonian: Ridala). In spring of 1211 Bishop issued the "Albert Privilege" to attach to Riga the main economical force - long-distance merchants. In 1212, Polotsk gave up its tributary rights over Gerzika (Latvian: Jersika) in favor of Bishop Albert, and Smolensk (Russian: Смоле́нск), Polotsk and other princes' messengers arrived in Riga, where they signed the trade agreement. Bishop Albrecht's brother Theodericus, who already in 1191 arrived at Estonian lands, in order to expose the Gauja Waterway moved to northwestern Russia, where on the way to the country were big centres Pskov and Novgorod, already familiar to the Germans, became Vogt of the Livs' land Vidumaa. Estonian historian of art Kaur Alttoa (b. 1947) believed, that in the 13th century, after a long struggle in 1227, when Estonians fell under foreign rule and were subjected to Christianity, a new stage in history began (Alttoa, 1986, LVIII).

Brothers-knights obtained trade roads on the Gauja foreland. In 1224, the Brothers of the Sword instead of Estonian wooden fortress started to build Fellin stronghold (Atskaņu, 1998, 313) adapted to hillfort's relief (Fig. 7), developed the settlement behind the castle and signed with Bishop of Riga Albrecht the contract of Tolowa partition (Senās, 1937). The residence was included in the common defensive system of a fortified building complex.

The new political and idiological situation led to fundamental changes in many areas of culture, including in architecture. Relations with Northern and Western Europe strengthened. Along with agrarian settlements, towns developed as administrative centers. In construction, religious architecture was highlighted, although the importance was attached to fortifications. Fundamental changes took place in construction technology, which were previously unknown here: stone 
masonry on lime mortar, arches and vaults spread, fired brick was used. In South Estonia, from materials dominated bricks and boulders. The first castles in Estonia were often built on the site of ancient settlements. They had wooden structures, which were gradually replaced by stone. As a rule, they were laid on natural hills, but there were fortifications, the defense of which were mainly based on water. The most ancient type of fortifications were castles of irregular layout. Their territory was surrounded by a wall in accordance with the configuration of the terrain. Such castles became especially widespread immediately after the period of conquest (Alttoa, 1986).

At the Melnupite (the Black River) also Dzirnupitte, or Rātsupite River estuary in the Gauja, warriors after 1224 built Wolmar Castle (Fig. 8) on an elongated triangular cape by steep slopes (Berga, 2002, 2003, 2011). The stone fortress, protected from the south by the Gauja River and a millpond in the east and north sides, had defensive walls (Berga, 2010), adjusting the trace to peculiarity the pond's edge, relief and a bank the river. North and south blocks of Wolmar Castle, mutually placed in a narrow angle, and a small closing building between blocks created a triangular volume. In the east, where the residence located, there was no defensive wall. The yard obtained a symmetrical triangular trapezoid layout, partite into two parts.
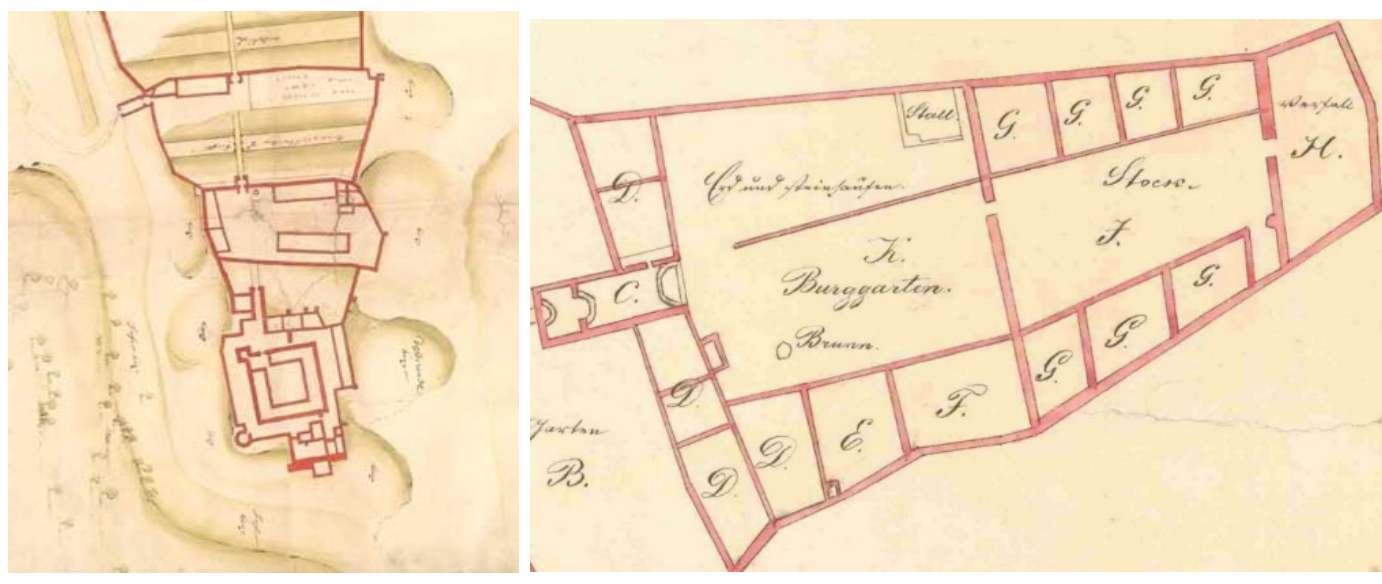

Figure 7 Karl Woldemar von Löwis of Menar. Plan of Fellin Fortress included the castle and front-castles. In 1914 created after plan (1602) drawn by Jacobus Laubus (Löwis, 1922, 146)

Figure 8 Wolmar Castle plan around the yard created by two lateral blocks and a northern block and the front-castle with the yard. 1688 (State Archives of Latvia, Fund 6828, Description 2, Case 464-a, File 2)

It was possible, that there was also a northern block. One courtyard in the stone fortress located between the side bodies and the parham, but the other was in the front-castle. The paved courtyard had a large funnelled well. A masonry wall separated both courtyards in a north-south direction (Berga, 2018, 21). The 
exact year of Wolmar Castle as the first military fortification of the Livonian Brothers of the Sword is unknown. Researcher of medieval architecture Armin Tuulse considered that Wolmar fortification originally was built as a temporary wooden structure, but later the stone fortress was erected. Historian Arveds Švābe supported this view, and he believed, that wooden fortifications were built immediately after the partition of Tholowa in 1224, when the Livonian Brothers of the Sword got the land upstream the Gauja. Professor Mugurēvičs considers, if accepted, that Wolmar wooden fortifications were built after 1224, then it becomes understandable, why the mansonry fortress and a church of stone took place simultaneously at the end of the $13^{\text {th }}$ century (Mugurēvičs, 1983).

\section{Conclusions}

1. In Livonia, during the first building period, fortresses were built on an elevated relief, and they reminded of fortified yards. The chapel was also included in the perimeter building.

2. In Livonia, population of the German power centres developed under the cover of the fortress, creating an urban construction structure, included in the common fortification system. The ditch or a water obstacle separated the fortress area from the settlement, which centre with a marketplace and the congregation's church obtained an independent planning.

\section{References}

Alttoa, K. (1986). Estonija. Istoricheskij ocherk. In Pamjatniki iskusstva Sovetskogo Sojuza: Belorussija, Litva, Latvija, Estonija. Spravochnik - putevoditel. Moskva, Leipzig: Izdatelstvo Iskusstvo, VEB Interdruck Leipzig, LVII-LXX.

Apala, Z. (2007). Cēsu pils arheologiskās izpētes (1974-2006) rezultāti. In Quo vadis, Cēsis? Vêsture un mūsdienu nosacījumi pilsētas attīstībai (45-75). Cēsis: Cēsu pašvaldības ağentūras Vidzemes Vēstures un tūrisma centrs.

Apals, J. (2007). Cēsis un vendi. In Quo vadis, Cēsis? Vēsture un mūsdienu nosacījumi pilsētas attīstībai (25-44). Cēsis: Cēsu pašvaldības aǵentūras Vidzemes Vēstures un tūrisma centrs.

Apals, J. (1998). Vendi un Cēsu Riekstu kalns. In Senā Rīga: Pētījumi pilsētas arheologiijā un vēsturēe, Volume 1.(125-143). Rīga: Latvijas vēstures institūta apgāds.

Apals, J. (2002). Ordeņa un bīskapa piḷu celtniecības stratēǵija Gaujas baseinā 13. - 14. gadsimtā. In Latvijas viduslaiku pilis III. Pêtījumi par ordeņpilìm Latvijā (197-214). Rīga: Latvijas vēstures institūta apgāds.

Arbusow, L. (1904). Livlands Geistlichkeit vom Ende des 12. bis ins 16. Jahrhundert. Jahrbuch für Genalogie, Heraldik und Sphragistik für 1900-1902. Mitau: Steffenhagen.

Atskaņu hronika. (1998). Rīga: Zinātne.

Benninghoven, F. (1965). Der Orden der Schwertbrüder: fratres milicie Christi de Livonia. Köln-Graz: Böhlau Verlag. 
Ozola, 2020. Planning and the Spatial Solution of Fortified Urban Structures in Secular Power

Centres Built by the Livonian Brothers of the Sword (1202-1237)

Berga, T. (2002). Valmieras ordeṇpils arheoloǵiskā izpēte (1988-1996). In Latvijas viduslaiku pilis, III. Pètījumi par ordenpilīm Latvijā (269-295).Rīga: Latvijas vēstures institūta apgāds.

Berga, T. (2011). Valmieras pils austrumu daḷas apbūve. In Latvijas viduslaiku pilis, VII. Pètījumi un avoti par Livonijas ordenpilīm (160-178). Rīga: Latvijas vēstures institūta apgāds.

Berga, T. (2003). Valmieras pils: arheologa stāsts. Valmiera: Valmieras novadpētniecības muzejs.

Berga, T. (2018). Valmieras vecpilsētas arheologija. Rīga: Zinātne.

Berga, T. (2010). Viduslaiku Valmieras aizsargmūris. In Arheologija un etnogrāfija. XXIV (112-124). Rīga: Zinātne.

Berkholce, E. (1952-1953). Apcerējums par Cēsu būvniecības vēsturi. Rīga: manuscript typewritten (Archives of Cēsis History and Art Museum, file of the Old town of Cēsis Nr. 46685- I)

Borowski, T. (2010). Miasta, zamki i klasztory państwa krzyżowego, Zakonu Szpitala Najświętszej Marii Panny, Domu Niemieckiego w Jerozolimie, nad Bałtykiem: Inflanty. Warszawa: Wydawnictwo Volumen. Oficyna Wydawnicza M. Łatkowska.

Broce, J.K. (2007). Zīmējumi un apraksti. 4. sējums: Latvijas mazās pilsētas un lauki. Rīga: Latvijas vēstures institūta apgāds.

Caune, A., \& Ose, I. (2004). Latvijas viduslaiku pilis IV. Latvijas 12. gadsimta beigu - 17. gadsimta vācu pil̨u leksikons. Rīga: Latvijas vēstures institūta apgāds.

Dirveiks, I. (2002). Cēsu pils arhitektoniski-mākslinieciskā inventarizācija. Rīga: Arhitektoniskās izpētes grupa (manuscript in Archives of Cēsis History and Art Museum).

Dzenis, A. Cēsu pils vēsture. Retireved from http://pilsvesture.cesis.lv/vesture/15-nodala-cesupils-apbuves-vesture/

Dzimtene. Cēsis. (1927). In Latvijas Kareivis Nr. 128, 11. jūnijs.

Dzirkalis, K. (1935). Rekonstruēsim senču pili Cēsu Riekstu kalnā. Cēsu Vēstis, 112, 23 August.

Egli, E. (1959). Geschlchte des Stadtebaues. Erster Band. Die alte Welt. Zurich und Stuttgart.

Endzelīns, J. (1931). Par Cēsu un Cesvaines vārdu. Filologu biedrības raksti, 11, 198-200.

Fjodorovs, D. (1961). Cēsu pils vēsturiskā izpēte, Volume 2. Rīga: Arhīva materiāli. Inv. Nr. 92018 III.

Gadebusch, F.K. (1772). Abhandlung von Livländischen Geschichtschreibern. Riga: Johann Friedrich Hartknoch.

Gadebusch, F.K. (1846). Ein Blick auf die Ruinen der Schlösser in Livland. Das Inland, 32, 6 August.

Grushka, E. (1963). Razvitie gradostroitelstva. Bratislava: Izdatelstvo Slovackoj Akademii Nauk.

Heine, V. (1994). Piezīmes Valmieras vēsturei. Senā Valmiera. Valmiera: Vācu kultūras biedrïba.

Heine, W.F. (1893). Beiträge zur Geschichte der Stadt Wolmar. Rigasche Stadtblätter, Nr. 43-51.

Heinrici Chronicon = Indriķa hronika (1993). Rīga: Zinātne.

Jemeljanovs, E. (2014). Kur atradās mestra Venno celtā pirmā Siguldas ordeņpils. In Latvijas viduslaiku pilis VIII. Pētījumi un avoti par orden,a un bīskapu pilīm Latvijā (132-144). Rīga: Latvijas vēstures institūta apgāds.

Jansons, A. (1958). Cēsu pils vēsture. Rīga: manuscript. 
Jensen, V., Parikka, A., \& Kylsberg, B. (2013). Castles Around the Baltic Sea. Riga: Association of Castles and Museums around the Baltic Sea.

Kalniņš, G. (2014). Cēsu pils. Cēsis: Cēsu kultūras un tūrisma centrs.

Kalniņš, G. (2017). Cèsu pils ilustrēta vēsture. Cēsis: Cēsu kultūras un tūrisma centrs.

Kelch, Chr. (1695). Liefländische Historia, oder kurtze Beschreibung der Denkwürdigsten Kriegs- und Friedens- Geschichte Esth- Lief- und Lettlands. Reval: Verlegts Johann Mehner Buchhändler.

Latvijas PSR vēsture. 1. sējums. (1953). Rīga: Latvijas PSR Zinātnu Akadēmijas izdevniecība. Livländische Reimchronik mit Anmerkungen, Namenverzeichnis und Glossar. (1876). Paderborn: Druck und Verlag von Ferdinand Schöningh.

Loze, J. (1956). Livonijas ordeḷa Cēsu pils - ievērojams vēstures piemineklis. Cēsu Stars, 79, 5. jūlijs.

Von Löwis of Menar, K. (1922). Burgenlexikon für Alt-Livland. Riga: Walters und Rapa.

Mänd, A. (2009). Saints' Cults in Medieval Livonia. In The Clash of Cultures on the Medieval Baltic Frontier (191-223). London: Routledge. DOI: org/10.4324/9781315240626

Moora, H. (1956). Viljandimaa feodaalse killustumise perioodil (XIII-XVII sajandil). Viljandi: Viljandi Koduloomuuseum.

Mugurēvičs, E. (1983). Latvijas viduslaiku piḷu klasifikācijas un arheoloğiskās izpētes jautājumi. In Arheologija un etnogrāfija, XIV (3-13). Rīga: Zinātne.

Mugurēvičs, E. . (2000). Rakstītie avoti par bīskapa Alberta personību un vina darbību Livonijas valsts veidošanā. In Senā Rìga. Pētījumi pilsētas arheologijiā un vēsturē II (35-44). Rīga: Latvijas vēstures institūta apgāds.

Mugurēvičs, Ē. (1998). Rakstīto vēstures avotu senākās ziṇas par Rīgu 13. gadsimta pirmajā pusē. In Senā Rìga. Pètījumi pilsētas arheologijā un vēsturē (177-189). Rīga: Latvijas vēstures institūta apgāds.

Ozola, S. (2018a). The Development of the Catholic Cathedral Building-type at Bishoprics' Towns on the Baltic Sea Southern Coast during the $13^{\text {th }}-14^{\text {th }}$ Centuries. In Landscape Architecture and Art, 14(14), 23-43. DOI: 10.22616/j.landarchart.2019.14.03

Ozola, S. (2018b). The Tower House - the Strategically Significant Component of Power Centres' Fortified Building Complexes in Livonia and in the Tuetonic Order State during the $13^{\text {th }}-14^{\text {th }}$ Centuries. Daugavpils Universitātes 60 starptautiskās zinātniskās konferences rakstu krājums. $C$ daḷa Humanitārās zinātnes = Proceedings of the 60th International Scientific Conference of Daugavpils University. Part C Humanities, 166-198.

Pāvulāns, V. (1971). Satiksmes ceļi Latvijā XIV-XVII gs. Rīga: Zinātne.

Polis, J. (2006). Cēsu hronika. Cēsis: Cēsu kultūras biedrība HARMONIJA.

Raadik, E. (1960). Viljandi arhitektuuri ajalugu feodalismi perioodil (XIII-XIX sajandi keskpaigani). Tartu: Tartu Riiklik Ulikool.

Savarenskaja, T.F. (1984). Istorija gradostroitelnogo iskusstva. Moskva: Strojizdat.

Senās Latvijas vēstures avoti. (1937). Rīga: Latvijas Vēstures institūta apgāds.

Von Sivers, J. (1852). Wenden, seine Vergangenheit und Gegenwart: Ein Beitrag zur Geschichte Livlands. Riga: Nicolai Kummel's Buchhandlung.

Spekke, A. (2008). Latvijas vēsture. Rīga: Jumava.

Šterns, I. (2002). Latvijas vēsture. 1180-1290: Krustakari. Rīga: Latvijas vēstures institūta apgāds.

Švābe, A. (1921). Latvju kultūras vēsture, II: Feodālā satversme. Rīga: A. Gulbja apgāds.

Tuulse, A. (1942). Die Burgen in Estland und Lettland. Dorpat: Dorpater Estnischer verlag. 
Ozola, 2020. Planning and the Spatial Solution of Fortified Urban Structures in Secular Power

Centres Built by the Livonian Brothers of the Sword (1202-1237)

Vanags, K. (1937). Cel̦vedis pa dzimto zemi. 1. dal̦a. Vidzeme un Latgale. Rīga: Sabiedrisko lietu ministrijas Tūrisma nodaļa.

Vasiljev, J.M. (1986). Latvija. Istoricheskij ocherk. In Pamjatniki iskusstva Sovetskogo Sojuza: Belorussija, Litva, Latvija, Estonija. Spravochnik - putevoditel. Moskva, Leipzig: Izdatelstvo Iskusstvo, VEB Interdruck Leipzig, XL-LVI.

Vasmanis, D. (2007). Cēsu pilsētas main̄̄gā vēsture no viduslaikiem līdz 19. gadsimta beigām. In Quo vadis, Cēsis? Vèsture un mūsdienu nosacījumi pilsētas attīstībai (121-134). Cēsis: Cēsu pašvaldības ağentūras Vidzemes Vēstures un tūrisma centrs.

Zeida, A., \& Zeids, T. (1961). Amatniecības attīstība Cēsīs feodālisma laikmetā. Vèstures problēmas, 4, 86-92.

Zeids, T. (1992). Senākie rakstītie Latvijas vēstures avoti: līdz 1800. gadam. Rīga: Zvaigzne.

Zilgalvis, J. (2000). Latvijas pērles: kultūrvēsturisks celvedis pa 40 skaistākajām Latvijas pilīm un muižām. Rīga: Rīga AGB 2000.

Zilgalvis, J., Tapiņa, I., \& Šnē, A. (2004). 100 apdraudētākie kultūras pieminekḷi Latvijāa. Eiropas kultūras mantojuma dienas 2004. Rīga: Valsts kultūras pieminekḷu aizsardzības inspekcija. 